Protestantismo em Revista é licenciada sob uma Licença Creative Commons.

http://dx.doi.org/10.22351/nepp.v43i2.2817

\title{
Sobre o conceito de corresponsabilidade na eclesiologia de João Calvino
}

\author{
About the concept of co-responsibility in the ecclesiology of John Calvin
}

Gladson Pereira da Cunha*

\begin{abstract}
Resumo
O objetivo deste artigo é analisar, de maneira introdutória, a eclesiologia do reformador francês João Calvino, procurando nela elementos que sirvam de aporte para a elaboração de um modelo de corresponsabilidade eclesiástica. Essa análise considera como hipótese que o conceito de sacerdócio real de todos os crentes é a chave interpretativa dentro da eclesiologia de Calvino, que possibilitaria a percepção da existência de um princípio de envolvimento da igreja, enquanto comunidade, tanto na sua administração como no desempenho de sua missão como agência do reino de Deus.
\end{abstract}

\section{Palavras-chave}

João Calvino. Corresponsabilidade. Eclesiologia. Igreja. Ministérios.

\begin{abstract}
The aim of this paper is to analyze, in an introductory way, ecclesiology French reformer John Calvin, looking for it elements which serve as input for the preparation of an ecclesiastical co-responsibility model. This analysis considers like hypothesis that the concept of the royal priesthood of all believers is the interpretive key within the ecclesiology of Calvin, which would enable the realization of the existence of a principle involvement of the church, as a community, both in its administration as in the performance of its mission as an agency of the kingdom of God.
\end{abstract}

Keywords

John Calvin. Co-responsibility. Ecclesiology. Church. Ministries.

\section{Introdução}

O princípio de corresponsabilidade tem permeado o debate da administração pública. Nesse debate, acerca do lugar e papel comunitário da sociedade em tomar parte de decisões que sejam de importância coletiva, setores estatais têm valorizado a

[Texto recebido em agosto de 2016 e aceito em junho de 2017, com base na avaliação cega por pares realizada por pareceristas ad hoc]

* Docente da Graduação em Teologia da Escola de Ensino Superior Fabra, Serra/ES. Doutorando em Teologia (PUC-Rio). Mestre em Ciências da Religião (UPM). Especialista em Filosofia e Psicanálise (UFES). Graduado em Teologia (UPM). E-mail: gladsoncunha@gmail.com 
participação popular em organizações que os assessoram, criando assim modelos de gestão participativa. Mas, esse tema não está restrito ao ambiente estatal, até mesmo às empresas privadas. $\mathrm{O}$ conceito de responsabilidade compartilhada tem sido discutido como uma possibilidade de gestão.

Esse conceito também tem encontrado guarita dentro das instituições religiosas, em nosso caso específico, a Igreja de Jesus Cristo. O conceito de corresponsabilidade para fomentar o envolvimento de participação de seus membros naquela que é considerada a sua razão de ser, isto é, a missão.

Ao que parece, a temática da corresponsabilidade tem feito parte do esforço da Igreja Católica a partir o Concílio Vaticano II. Na Lumen Gentium (LG), a constituição dogmática sobre a Igreja, o Vaticano II iniciou a reflexão sobre o lugar e papel do laicato, enquanto parte da Igreja, no que dizer respeito a missão de Deus no mundo. A LG afirma:

Os sagrados pastores reconhecem perfeitamente quanto os leigos contribuem para o bem de toda a Igreja. Sabem que os pastores não foram instituídos por Cristo para assumirem sozinhos toda a missão da Igreja quanto a salvação do mundo, mas que o seu excelso múnus é apascentar os fiéis e reconhecer-lhes os serviços e carismas, de tal maneira que todos, a seu modo, cooperem unanimemente na tarefa comum. ${ }^{1}$

A compreensão do envolvimento do leigo surgiu dentro do âmbito geral que deu origem ao Concílio. Pode-se considerar que a ênfase dada ao ofício religioso do clero, principalmente na Idade Média e no período posterior à Reforma Protestante, até mesmo por questões relativas ao momento histórico, em detrimento do laicato, pode ter contribuído para uma percepção da responsabilidade única do clero.

Ainda dentro do âmbito do Vaticano II, o Decreto Apostólico Apostolicam Actuositatem, cujo subtítulo é Sobre o Apostolado dos leigos, traz ainda mais luz sobre o tema:

A Igreja nasceu para tornar todos os homens participantes da redenção salvadora (1) e, por eles, ordenar efectivamente a Cristo o universo inteiro, dilatando pelo mundo o seu reino para glória de Deus Pai. Toda a actividade do Corpo místico que a este fim se oriente, chama-se apostolado. [...] Mais ainda: é tanta neste corpo a conexão e coesão dos membros (cfr. Ef. 4.16), que se deve dizer que não aproveita nem à Igreja nem a si mesmo aquele membro que não trabalhar para o crescimento do corpo, segundo a própria capacidade. ${ }^{2}$ [grifo nosso]

E, em tempos mais recentes, o Papa Joao Paulo II afirmou em sua carta encíclica Slavorum Apostoli (19), que "a catolicidade da Igreja se manifesta, igualmente, na

1 LUMEN GENTIUM, 31. In: Documentos do Concílio Vaticano II. 2. ed. São Paulo: Paulus, 2002. p. 147.

2 DECRETO APOSTÓLICO APOSTOLICAM ACTUOSITATEM. In: Documentos do Concílio Vaticano II. 2. ed. São Paulo: Paulus, 2002. 
corresponsabilidade ativa e na colaboração generosa de todos em favor do bem comum". ${ }^{3}$ Deste modo, o Pontífice Romano demonstrou uma necessidade que os membros da Igreja de Cristo, e não apenas da Igreja Católica Romana, estejam conscientes e alinhados com uma urgente e necessária ação no mundo do qual ela faz parte.

Ao que parece, a ideia do envolvimento de todos os batizados na missão da Igreja é recente dentro Igreja Católica Romana, não desconsiderando quaisquer ações anteriores ao Concílio, apenas desconhecendo-as. Contudo, esse tema tem sido discutido pelo Movimento Reformatório desde o século XVI. As Igrejas instituídas a partir da Reforma Protestante romperam com a estrutura distintiva entre clero e laicato - salvo algumas exceções no luteranismo e no anglicanismo e seus correlatos que mantiveram o episcopalismo como modo de governo eclesial.

Grande parte dessa ruptura deve-se ao conceito do sacerdócio universal de todos os crentes, que serviu para pôr, no mesmo nível, aqueles que estavam diferenciados, embora, como fica evidente numa observação da teologia dos reformadores, os ministérios ordenados não sejam eliminados, eles são resignificados. E assim, de forma irrestrita, a doutrina do sacerdócio de todos os crentes passou a ser um dos pilares da Reforma, sendo primeiramente exposta por Lutero e pelos que o sucederam nesse movimento, entre eles, João Calvino, o reformador francês de Genebra. Pode-se, portanto, dizer, e evitando qualquer anacronismo, que a doutrina do sacerdócio universal de todos os crentes serviu como o gérmen para a prática da corresponsabilidade, isto é, a ação de todos os batizados no exercício daquilo que é a missão da Igreja.

O objetivo, portanto, desse artigo é analisar, mesmo que introdutoriamente, a eclesiologia do reformador francês João Calvino, procurando nela elementos que sirvam de aporte para a elaboração de um modelo de corresponsabilidade eclesiástica. Essa análise considera como hipótese que o conceito de sacerdócio real de todos os crentes é a chave interpretativa dentro da eclesiologia de Calvino, que possibilitaria a percepção da existência de um princípio de envolvimento da igreja, enquanto comunidade, tanto na sua administração como no desempenho de sua missão como agência do reino de Deus.

Deste modo, construiremos nossa análise a partir do conceito calviniano de igreja até alcançarmos o seu conceito de sacerdócio real de todos os crentes, para delinearmos como é possível perceber, na teologia de Calvino, aportes para uma teologia da corresponsabilidade.

3 JOÃO PAULO II. Carta Encíclica Slavorum Apostoli. Disponível em: <http://w2.vatican.va/content/johnpaul-ii/pt/encyclicals/documents/hf_jp-ii_enc_19850602_slavorum-apostoli.html >. Acesso em: 14 out. 2015. 


\section{Elementos-chave para compreensão da eclesiologia de Calvino}

O primeiro passo para atingirmos o que fora acima proposto é compreendermos o conceito de Calvino a respeito da Igreja. Calvino tinha uma compreensão peculiar da Igreja e o seu papel na vida do cristão. Devemos lembrar que o princípio calviniano da salvação tem como fundamento último a misteriosa eleição de Deus. ${ }^{4}$ Por meio dela e mediante Jesus Cristo, os eleitos se tornam "participes da salvação e da eterna beatitude trazida por Cristo" ${ }^{5}$

Nesse sentido, a Igreja teria como sua função essencial fornecer um itinerário para os crentes que os conduzisse a Deus, a despeito de toda a fraqueza humana que tenazmente se oporia a essa aproximação. A igreja, para Calvino, seria o meio de perpetuação da obra redentiva de Cristo e da própria eleição, contra a vaidosa índole humana que necessita de auxílios externos para que a fé progrida em sua meta proposta. ${ }^{6}$ Para Calvino, dada a grande e profunda diferença entre Deus e a humanidade, o próprio Deus somente poderia se relacionar com o seu povo por meio de uma aliança. ${ }^{7}$ Sendo, a Teologia da Aliança, uma marca de corpo teológico e, ao mesmo tempo, um de seus pressupostos, Calvino recomendou sua exposição, porquanto, ela seria uma chave interpretativa para as relações entre o Antigo e o Novo Testamento, além de seu conteúdo fundamentalmente cristológico. "Portanto", dizia Calvino, "exponhamos diante de todos a aliança que [Deus] sancionou eternamente e jamais interrompeu. O complemento dela é o Cristo, donde alcança até que seja estabelecida e ratificada". ${ }^{8}$

É a partir dessa compreensão que Calvino entende a Igreja como mãe e mestra de todos os crentes, ${ }^{9}$ porquanto, é por Cristo que Deus estabelece "o tratado [pacto] gratuito pelo qual Deus adotará seus eleitos". 10 Não será sem críticas posteriores que Calvino assumirá essas metáforas eclesiológicas, as quais são compreendias como inadequadas e desgastadas, principalmente por parte do movimento de Reforma que se tornou aderente ao anabatismo e sua proposta radical. ${ }^{11}$ A despeito disso, essas são as figuras que se fazem presentes, não apenas nas Institutas, mas também nos comentários bíblicos de Calvino, principalmente nos dedicados às cartas pastorais do apóstolo Paulo, ${ }^{12}$ o que demonstra

\footnotetext{
CALVINO, João. Instituições da Religião Cristã. Tomo II. São Paulo: Unesp, 2009b. p. 467.

CALVINO, 2009b, p. 465.

CALVINO, 2009b, p. 465.

CALVINO, João. Instituições da Religião Cristã. Tomo I. São Paulo: Unesp, 2009a. p. 411.

CALVINO, 2009a, p. 431.

CALVINO, 2009b, p. 465.

CALVINO, 2009a, p. 328.

GEORGE, Timothy. A Teologia dos Reformadores. São Paulo: Vida Nova, 2000. p. 236.

2 Comentando 1Timóteo 3.15, Calvino escreve: "Daqui se torna fácil deduzir o sentido que tinham as palavras de Paulo. A Igreja é a coluna da verdade porque, através de seu ministério, a verdade é preservada e difundida. [...] Ou, expondo-o de maneira mais simples: não é a Igreja a mãe de todos os crentes, visto que ela os conduz ao novo nascimento pela Palavra de Deus, educa e nutre toda a sua vida, os fortalece e finalmente os guia à plenitude de sua perfeição? A Igreja é chamada coluna da verdade pela mesma razão, pois o ofício de ministrar a doutrina que Deus pôs em suas mãos é o único meio para a
} 
seu comprometimento com essa ideia e o seu ensino. O fato é que, para a teologia concernente a igreja, Calvino tinha nessas duas metáforas a verdadeira indicação do propósito da Igreja.

[A] Igreja, em cujo seio Deus quer reunir seus filhos, de modo que sejam nutridos por seu ofício e ministério não só enquanto crianças, mas também na idade adulta, prolongando seu cuidado maternal até alcançarem o que a fé lhes promete. Não é lícito, de fato, separar essas duas realidades que o Senhor uniu (Mc 10.9), a saber: que a Igreja é mãe daqueles de quem Deus é o Pai. ${ }^{13}$

Entendida a razão de ser da Igreja, precisamos dar mais um passo à frente para compreendermos a eclesiologia de Calvino. Calvino segue o princípio clássico da Igreja como a communio sanctorum, termo que Calvino toma emprestado do Credo Apostólico, que ele está comentando em sua Institutas, para afirmar a necessidade da Igreja. ${ }^{14}$ Para ele, a expressão comunhão dos santos, presente no Símbolo, exprimiria “bem a natureza da Igreja, pois faz alusão ao fato de os santos estarem de tal modo agregados à sociedade de Cristo que mutuamente comunicam os dons que Deus lhes conferiu". ${ }^{15}$ Portanto, "se os fiéis estiverem verdadeiramente persuadidos de que Deus é o Pai comum de todos, e de que Cristo é a Cabeça, então estarão unidos entre si pelo amor fraterno, comunicando mutuamente o que têm" ${ }^{\prime \prime}{ }^{16}$ Não se tratava de, para Calvino, simplesmente estar ligado a uma instituição ou coisa semelhante. A Igreja representa em todos os sentidos a participação dos eleitos na salvação. Nesse sentido, já que Calvino de maneira alguma rejeita a ideia ou o termo sacramento, seria possível afirmarmos que a igreja era, para Calvino, o sacramento da salvação, tal como o próprio Concílio Vaticano II considerou em LG 1,9. Óbvio que há aqui um enorme anacronismo, contudo, não em termos de significado conceitual.

Na realidade, não é suficiente ter em mente que Deus preserva seus eleitos, caso não levemos em conta também a unidade da Igreja, de modo que estejamos verdadeiramente persuadidos de que pertencemos a ela. Pois, se não estivermos unidos aos outros membros sob o Cristo Cabeça, nenhuma esperança de herança futura nos resta. ${ }^{17}$

Nesse sentido, ressoa por toda as Institutas e em seus comentários bíblicos o conceito de Cipriano de Cartago: "extra ecclesiam nulla salus". ${ }^{18}$ Para Calvino, não há

preservação da verdade, a qual não pode desaparecer da memória dos homens". Cf. CALVINO, João. Pastorais. São José dos Campos: Fiel, 2009. p. 95-96.

13 CALVINO, 2009b, p. 465-466.

14 CALVINO, 2009b, p. 467.

15 CALVINO, 2009b, p. 467.

16 CALVINO, 2009b, p. 468.

17 CALVINO, 2009b, p. 467.

18 CALVINO, 2009b, p. 469. Essa ideia se faz presente, por exemplo, na última das grandes confissões protestantes de viés calvinista, a Confissão de Fé de Westminster, quando afirma sobre a Igreja: “A Igreja 
qualquer sentido de esperança fora da unidade estabelecida como sinal e sacramento por meio da igreja. Essa comunhão dos santos, segundo Calvino, segue em duas direções distintas e complementares - ela é tanto vertical quanto horizontal - possui uma dimensão salvífica e santificadora para aqueles que nela estão agregados, porquanto, "Deus a separa do resto da humanidade e a une a si mediante a Palavra e o Espírito" ${ }^{19}$ sendo Cristo a fonte por excelência da salvação e santidade da Igreja.

Diante da communio sanctorum, temos dois conceitos que são percebidos: pluralidade e unidade. ${ }^{20} \mathrm{O}$ primeiro identifica a diversidade existente dentro da Igreja, o segundo demonstra como essa pluralidade se articula para dar lugar a unidade. A catolicidade da igreja se resolve na unidade realizada mediante Jesus Cristo, o seu cabeça, conforme Calvino nos mostra abaixo:

Eis por que a Igreja diz-se católica ou universal, visto não ser possível encontrar duas ou três sem que Cristo esteja dividido, o que, aliás, não pode suceder. De tal modo os eleitos de Deus estão unidos em Cristo que, assim como dependem todos de uma única Cabeça, do mesmo modo constituem um só corpo. ${ }^{21}$

Calvino não nega a catolicidade da igreja. Para ele, segundo Barth, "existe uma igreja, uma comunhão dos santos, um povo de Deus, do qual Cristo é o príncipe, o líder e a cabeça do corpo". ${ }^{22}$ Como cabeça dessa Igreja que é simultaneamente visível e invisível, Cristo rege seu corpo por meio de seus ministros, os quais integram cada parte do corpo, isto é, os membros da Igreja à sua Cabeça, de modo que todos passam a estar "unidos por ligaduras semelhantes àquelas que há nos membros do corpo humano". ${ }^{23}$

Para determinar o que se poderia reconhecer como manifestação externa da igreja, Calvino considerou a existência de duas marcas que caracterizariam a Igreja de Cristo, as quais seriam o correto ensino da Palavra e a correta administração dos sacramentos. Sobre isso ele escreve:

Eis então de que modo a face da Igreja se manifesta ante nossos olhos: onde a Palavra de Deus é sinceramente pregada e ouvida, e vemos que os

visível, que também é católica ou universal, sob o Evangelho (não sendo restrita a uma nação, como antes sob a Lei), consiste de todos aqueles que, pelo mundo inteiro, professam a verdadeira religião, juntamente com seus Filhos; é o Reino do Senhor Jesus Cristo, a casa e família de Deus, fora da qual não há possibilidade de salvação". CONFISSÃO DE FÉ DE WESTMINSTER. 17. ed. São Paulo: Cultura Cristã, 2001. XXV:2.

19 LARRIBA, Jesus. Eclesiología y Antropología en Calvino. Madrid: Cristandad, 1975. p. 124.

20 LARRIBA, 1975, p. 76.

21 CALVINO, 2009b, p. 467.

22 BARTH, Karl. The Theology of Joh Calvin. Grand Rapids: Wm. B. Eerdemans, 2000. p. 178.

23 CALVINO, 2009b, p. 467. 
sacramentos são administrados segundo a instituição de Cristo, não podemos de modo algum duvidar de que ali está uma igreja de Deus. ${ }^{24}$

Tendo em vista o que foi dito acima, é necessário compreender como a Igreja, segundo a concepção calviniana, se articula enquanto estrutura. Como se dá as relações entre os ministros estabelecidos por Deus e os demais membros das comunidades locais que formam a Igreja.

\section{A Igreja e os ministérios ordenados}

A Igreja, na eclesiologia de Calvino, não era uma entidade anárquica. Devemos ter em mente que um dos conflitos que se deu no período da Reforma foi um anticlericalismo exacerbado por de muitos grupos que integraram o movimento reformatório. Por um lado, tinha-se a estrutura hierárquica do catolicismo, do outro, essa compreensão anticlerical beirando a anárquica - que se pode perceber, ainda hoje, em grupos oriundos dos movimentos anabatistas. ${ }^{25}$ Calvino traz em seu modelo de governo eclesiástico uma nota conciliadora entre a hierarquia e o anticlericalismo. ${ }^{26}$ Para ele,

do mesmo modo, como outrora não se limitou a entregar a Lei, mas estabeleceu sacerdotes como intérpretes, por cujos lábios o povo conhecesse o seu verdadeiro sentido, assim também hoje o Senhor deseja que nos apliquemos não somente à leitura pessoal, mas também à audição dos mestres por Ele estabelecidos para nos auxiliar nesse mister. ${ }^{27}$

Temos nessa afirmação, a verificação que o ministério ordenado, para Calvino, era um fato teologal, isto é, foi querido e pretendido por Deus que existissem homens, por ele instituídos, para o exercício do governo e cuidado de sua Igreja. ${ }^{28}$ A esses homens, os filhos de Deus e da Igreja, deveriam "deixar-se governar, com espirito manso e humilde", como se submetessem ao próprio Deus. Aliás, Calvino afirmou que "o Senhor se serve do ministério dos homens, tornando-os como que seus substitutos (et quasi vicariam operam)". ${ }^{29}$

24 CALVINO, 2009b, p. 474.

25 McINTIRE, C.T. Anticlericalismo. In: ELWELL, Walter A. Enciclopédia Histórico-Teológica da Igreja Cristã. São Paulo: Vida Nova, 2009. p. 81.

26 Segundo Wilson Castro Ferreira, "Calvino entendia que o sistema que convinha a Genebra podia não ser o ideal para um estado e igreja em diferentes circunstancias, daí pensarem alguns que que advogara um sistema semiepiscopal para a Polônia e que aprovara o governo episcopal para a Inglaterra". Percebe-se na afirmação de Ferreira, que Calvino possuía uma percepção um tanto mais amplo do ministério ordenado, não o restringindo a um modelo, embora, no caso do episcopado ele negue a validade da sucessão apostólica. FERREIRA, Wilson Castro. Calvino: Vida, influência e teologia. Campinas: LPC, 1990. p. 105. Sobre a sucessão apostólica, ver CALVINO, João. Institutas da Religião Cristãa: edição de estudo. v. 4. São Paulo: Cultura Cristã, 2011. p. 78.

27 CALVINO, 2009b, p. 470.

28 CALVINO, 2009b, p. 469.

29 CALVINO, 2009b, p. 501. Cf. CALVINUS, Ioannis. Institutio Christianae Religionis. Berolini: Gustav Eichler, 1835. IV: iii, p. 213. Disponível em: <http://www.ccel.org/ccel/calvin/institutio2/ Page_213.html>. Acesso em: 06 out. 2015. 
Decerto, ele tentou, por um lado, negar o vicariato católico, mas, por outro, ele queria afirmar a existência de elementos de mediação presente no ministério ordenado, como era o caso. Neste último caso, o seu conflito era contra os anabatistas.

O que Calvino estava dizendo é que Deus usa de homens para o governo de sua igreja e isso não pode ser negado, embora considere que esse governo eclesiástico não deveria ser considerado um meio escandaloso para se auferir poder e privilégios. De fato, tamanha era a importância que Calvino dava ao ministério ordenado, que chegou a afirmar que "Deus se serve [de ministérios] para governar a Igreja, [e que esses ministérios são] a força principal que une os fiéis num só corpo". ${ }^{30} \mathrm{Ou}$ ainda "Negar esse ministério seria como que apagar a face de Deus, que aos nossos olhos brilha pela pregação da doutrina". ${ }^{31}$ Logo, a Igreja deveria ser governada, conduzida e cuidada por pessoas que fossem estabelecidas por Deus para o exercício de determinado ministério, para os quais haveria uma determinada capacitação produzida pela presença do Espírito Santo. Isso nos deve nos conduzir à frente, a uma outra questão: como esses ministérios são percebidos na Igreja?

Primeiramente, precisamos de considera que dentro da eclesiologia de João Calvino, há um lugar específico para o exercício dos carismas, embora, a grande ênfase recai sobre aqueles dons que teriam, como objeto, a Palavra e seu ensino. Assim, Calvino relega os demais carismas a condição de extraordinários ou ainda transitórios. ${ }^{32}$ Aliás, ao comentar Efésios 4.11, Calvino considerou os próprios ofícios-carismáticos de apóstolo, profeta e evangelistas como ofícios transitórios na Igreja. ${ }^{33}$ De acordo com essa ideia de Calvino, o múnus apostólico e pastoral se manifestaria no presente da Igreja por meio de duas funções ou ofícios, isto é, entre os pastores e os mestres. ${ }^{34} \mathrm{E}$ sem pastores e mestres não pode haver nenhum governo da Igreja. ${ }^{35}$

Deve-se observar também que, dos ofícios que Paulo enumera, somente os dois últimos são de caráter perpétuo. Porquanto Deus adornou sua Igreja com apóstolos, evangelistas e profetas só por algum tempo, exceto que, onde a religião se encontra sucumbida, ele suscita evangelistas à parte da ordem da Igreja. ${ }^{36}$

Os critérios que Calvino utiliza para estabelecer os ofícios ordenados, em suas Institutas, são confusos e sua descrição, neste momento, não se faz necessária. No entanto, ao redigir Projeto de Ordenanças Eclesiásticas, de 1541, Calvino admitiu a existência de

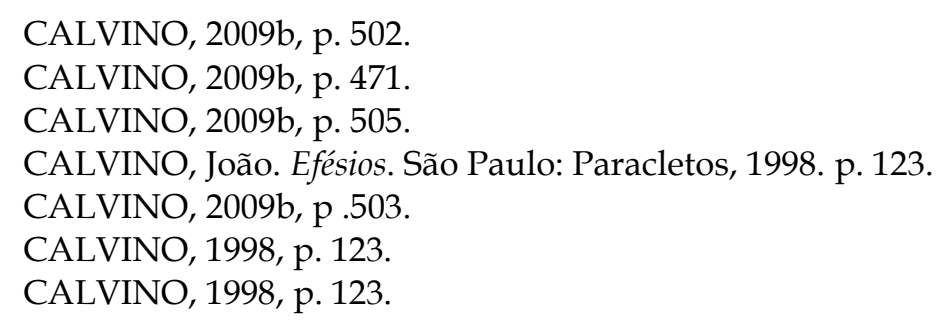


quatro ministérios ordenados, são eles: pastores, doutores, presbiteros e diáconos. ${ }^{37}$ Vejamos alguns detalhes pormenorizados desses ministérios.

Os pastores seriam os responsáveis pela pregação e ensino da Palavra, administração dos sacramentos e disciplina na igreja, bem como o governo da comunidade sobre a qual foi instituído ministro. ${ }^{38}$ Para definir esse conceito, Calvino intercala sem uma distinção muita clara os termos pastor, bispo, presbítero e ancião, os quais, segundo ele, assim também seriam utilizados sem essa clara distinção no Novo Testamento. ${ }^{39}$

\begin{abstract}
No que diz respeito ao verdadeiro ofício do presbítero [aqueles que Cristo manda que sejam ordenados como dispensadores do Evangelho e dos sacramentos], que nos foi encomendado pela boca do próprio Cristo, de boa vontade considero-o sacramento. Porque, em primeiro lugar, é uma cerimônia tirada da Escritura; e, além disso, não é vã nem supérflua, mas um símbolo fiel da graça espiritual, como atesta Paulo (1 Tm.4.14) $\cdot{ }^{40}$ [grifo nosso]
\end{abstract}

Nesse conjunto, segue-se aos pastores os doutores ou mestres, que eram responsáveis pela interpretação da Palavra e pelo ensino na Igreja, sendo negado a eles a administração dos sacramentos e da disciplina. ${ }^{41}$ Alguns estudiosos, como Ferreira, sugerem que não seriam ordenados, contudo, não fornecem subsídios para tal afirmação. ${ }^{42}$ O fato é que claramente o Projeto, de 1541, não descreve o rito simples elaborado por Calvino aplicado ao mestre, muito embora, seja sugestiva da ordenação: “Todos aqueles que estarão sujeitos à disciplina eclesiástica como ministros". ${ }^{43} \mathrm{Ou}$ seja, juramento às autoridades e às Escrituras. De maneira geral, "o oficio dos doutores ou mestres é ensinar os fiéis na sã doutrina, a fim de que a pureza do evangelho não seja corrompida ou por ignorância ou por

37 CALVIN, Jean. Projet D'ordonnances Ecclesiastiques (1541). In: CUNITZ, Edouard et al. (Eds.) Joannis Calvini opera quae supersunt omnia. Tomo 10. Brunsvigae: C.A. Schwetschke, 1863. p. 15-16.

38 CALVINO, 2009b, p. 505.

39 A Igreja Presbiteriana do Brasil (IPB) reconhece que, como pensou Calvino, as Escrituras dão uma série de títulos ao ministro da Palavra e dos Sacramentos, entre os quais, o título bispo está presente. De fato, o que se tem dentro do sistema da IPB é um sistema episcopal simplificado e circunscrito a uma igreja local, uma vez que o ministro, que é conhecido pelo título de presbitero docente, preside um conselho de presbíteros, também denominados de presbíteros regentes, os quais têm a tarefa de cuidar da vida e do exercício da disciplina na comunidade local. Mas também está sob a gerência do ministro um corpo diaconal, responsável pela ação social da comunidade. Cf. CONSTITUIÇÃO DA IGREJA PRESBITERIANA DO BRASIL. In: Manual Presbiteriano. 16. ed. São Paulo: Cultura Cristã, 2014. p. 19.

40 CALVINO, 2009b, p. 867.

41 CALVINO, 2009b, p. 505.

42 FERREIRA, 1990, p. 105.

43 CALVIN, 1863, p. 22. 
malévolas opiniões". ${ }^{44}$ Os pastores e mestres formariam Companhia dos Pastores de Genebra ou como ainda era conhecida a Venerável Companhia. ${ }^{45}$

No exercício do seu ministério, no que diz respeito à administração eclesiástica e disciplinar, os pastores são auxiliados por conselho de anciãos ou presbíteros, que seriam escolhidos pela comunidade para um mandato anual. ${ }^{46}$ Esse terceiro ministério não estaria apenas a serviço de uma comunidade local, mas a representaria em conselhos distintos dentro da cidade. Eles seriam eleitos em número de doze presbíteros por igreja. ${ }^{47}$ Desse doze, quatro seriam representantes ao Conselho dos Sessenta, também chamado de Pequeno Conselho, e outros seis seriam representantes no Consistório de Genebra, ou Grande Conselho, formado por duzentas pessoas entre ministros ordenados e leigo, dos quais constavam os magistrados genebrinos. ${ }^{48}$

Deveria existir também em cada comunidade um colégio diaconal, que reuniriam os diáconos, que seriam o braço social da Igreja. Segundo Robert Kingdom, "provavelmente a principal contribuição teológica de João Calvino ao entendimento reformado do bem-estar social é aquela encontrada nas suas ideias acerca do diaconato". ${ }^{49}$ Comentando Romanos 12.8, Calvino considera que a o exercício de uma contribuição liberal da qual fala o apóstolo Paulo nesse versículo, tem a ver não com os que doam dos seus bens, mas "aos diáconos que se acham incumbidos da distribuição dos erários públicos da Igreja". ${ }^{50}$ Deste modo, Calvino mais uma vez relaciona o exercício de um ministério a um carisma divino. Mas não apenas isso, mas é nesse ponto que Calvino revoluciona a eclesiologia reformada e, porque não dizer, cristã, isto é, a inserção da mulher no ministério ordenado. Assim escreve Calvino:

Se não me engano, no primeiro caso, ele chama "diáconos" aqueles que distribuíam as esmolas; no segundo, aos que cuidavam dos pobres e doentes, por exemplo as viúvas mencionadas na Epístola a Timóteo (1Tm 5.10). Porque as mulheres não podiam ter nenhum oficio público a não ser o da assistência aos pobres. ${ }^{51}$

44 CALVIN, 1863, p. 21.

45 MATOS, Alderi Souza. João Calvino e a Disciplina em Genebra: Um Retrato Paradoxal. Fides Reformata, v. XVIII, n. 1, 2013. p. 65. Parece que Calvino tinha em mente um modelo de magistério eclesiástico similar ao existente na Igreja medieval, no qual paralelamente estavam os pastores-bispos (magisterium cathedrae pastoralis) e os doutores universitários (magisterium cathedrae magistralis), tal como comentou Tomás de Aquino, no século XIII. Cf. RAUSCH, Thomas P. A Teologia e seus Métodos. In: RAUSCH, Thomas P. (Org.). Introdução à Teologia. 2. ed. São Paulo: Paulus, 2009. p. 23.

46 FERREIRA, 1990, p. 104. CALVIN, 1863.

47 MATOS, 2013, p. 66.

48 CALVIN, 1863, p. 22.

49 KINGDON, Robert M. Calvin's Ideas about the Diaconate: Social or Theological in Origin? In: LINDBERG, Carter (Ed.). Piety, Politics, and Ethics. Kirksville: Sixteenthcentury Journal Publishers, 1984. p. 168.

50 CALVIN, John. Commentary on the Epistle to the Romans. Albany: AGES Library, 1998. p. 359.

51 CALVINO, 2009b, p. 508. 
Neste ofício, Calvino circunscrevia a ação das mulheres cristãs, "as mulheres não podiam ter nenhum ofício público a não ser o da assistência aos pobres". ${ }^{2} \mathrm{O}$ serviço das mulheres no diaconato não apenas contava com respaldo bíblico, como também tinha relação com a experiência da Igreja, na qual as mulheres têm servido à sociedade por meio de ações sociais, beneficência e cuidado com os mais necessitados. Nesse sentido, portanto, percebemos a possível participação de todos os cristãos nos ofício e ministérios da Igreja, desde que guardados os parâmetros que poderiam e deveriam ser considerados, quer estivesse relacionado com as responsabilidades inerentes ao ofício, quer fossem os parâmetros relacionados com o gênero para o exercício do oficio.

A questão do lugar da mulher no exercício ministerial da Igreja é um tema em que Calvino "é invulgar e intrigante para o século dezesseis, de maneira provável genuinamente inovador", 53 porquanto, para ele, as mulheres não poderiam ser isentas do serviço público na igreja de Cristo. Entretanto, Calvino compreendia, à luz da sua interpretação de 1Timóteo 2.11-12, que não competia às mulheres a tarefa do ensino eclesiástico, portanto, por essa razão, nãos lhes competia também o exercício pastoral, docente e mesmo o presbiteral, porque de alguma maneira a mulher estaria em posição de superioridade ao homem. ${ }^{54}$ Embora, não sem alguma contraposição quanto ao modo que Calvino interpretou esse texto, como faz a teóloga calvinista Jane Douglass, ao dizer que Calvino "nunca reivindica o ensino ou exemplo de Cristo como justificativa para a subordinação das mulheres na Igreja, mas se trata apenas de uma recomendação de Paulo e com a ordem da criação" ${ }^{55}$ Fato é que Calvino negava o exercício da liderança pelas mulheres, mas não as excluía do exercício diaconal. No entanto, como pode ser percebida na tradição reformado-calvinista, essa posição caiu em desuso. Até mesmo por causa falta de persistência de Calvino nesse tema que, como salientou Douglass, deixou de ser mais discutido levando em consideração o próprio momento existencial da Reforma em Genebra. ${ }^{56}$

Diante do que foi dito até aqui, surge uma terceira questão: o que determinava, além da vocação interna e capacitação espiritual, que certo indivíduo poderia exercer e ser ordenado a um oficio eclesiástico? Algo que Jesus Larriba deixou bem claro é que, para Calvino, "o corpo de Cristo não é uma comunidade puramente carismática, sem maiores vínculos que o consistente $m$ que todos os dons tenham a mesma origem e se ordenam ao mesmo fim". ${ }^{57}$ Sobre isso, Calvino escreve:

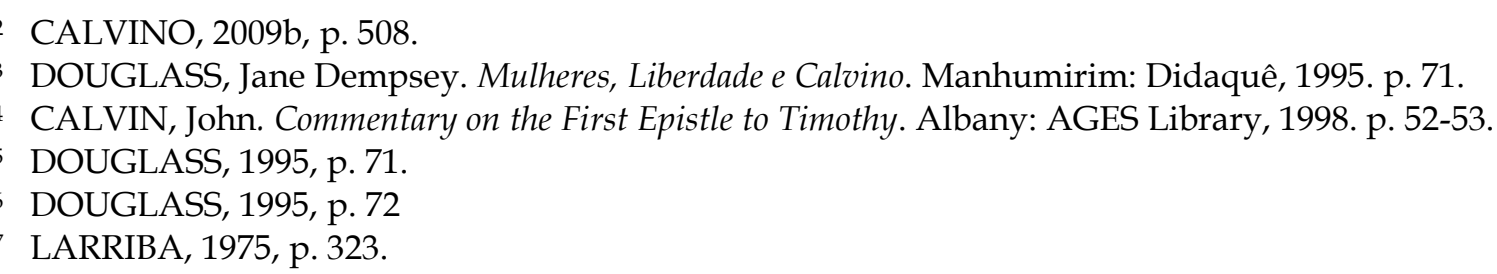


Tomou-se a precaução de que ninguém exercesse um ministério público na Igreja sem que fosse um vocacionado. Para alguém ser considerado verdadeiro ministro da Igreja, exige-se antes de tudo que tenha sido devidamente chamado [por ela]. ${ }^{58}$

Não devemos perder de vista a existência de um elemento de reciprocidade entre os ministros e a congregação. Se por um lado, os ministros exercem sobre a comunidade, por outro, é essa mesma comunidade que legitima a ação dos ministros, embora, como diz Larriba, haja também, em relação aos ministros, uma legitimação divina. Não obstante, no que diz à relação ministros-congregação, o princípio de reciprocidade permanece. Desta forma, podemos considerar que Calvino, em sua eclesiologia, inter-relaciona todos os indivíduos da comunidade a fim de que eles se articulem entre si, ao mesmo tempo em que todos estão articulados a Cristo e esse a Deus. Porém, uma questão surge aqui: $E$ somente nesta simples relação legitimadora que está o lugar de ação dos leigos? O sacerdócio universal dos crentes se resume apenas a isso? A resposta é simples: Não é apenas isso! Vejamos, então, o entendimento de Calvino acerca do sacerdócio universal de todos os crentes.

\section{O sentido do "sacerdócio real dos crentes" no contexto da eclesiologia de Calvino}

Como já vimos, a Igreja para Calvino era o corpo místico de Jesus Cristo, do qual todos os crentes se constituem seus membros. Nesse sentido, para Calvino, apenas por meio da articulação das diferentes partes existentes no corpo é que poderiam gerar o correto cumprimento da missão e propósito da igreja. Assim, Calvino alerta para a necessidade da multiplicidade de funções e ações para que cada uma das partes tenha o que realizar.

A unidade do corpo é de tal natureza que só pode ser preservada pela variedade de membros; e, por outro lado, enquanto os membros diferem uns dos outros em suas funções e habilidades, não obstante se acham de tal maneira conectados uns aos outros que alcançam o propósito de preservar a unidade do corpo. ${ }^{59}$

Calvino não pensa na igreja como uma sociedade igualitária, justamente por que a imagem de corpo, utilizada pelo apóstolo Paulo, transmite uma ideia de uma diferenciação funcional. Aliás, para o Reformado, "a igualdade, portanto, se põe em franco conflito com o bem-estar do corpo, visto que ela gera confusão, o que nos leva sucessivamente a um desastre imediato". ${ }^{60}$ Isso faz sentido quando consideramos que o conceito de corresponsabilidade se estabelece na relação dos diferentes. Em seu comentário de

58 CALVINO, 2009b, p. 508. Cf. LARRIBA, 1975, p. 324.

59 CALVINO, João. 1 Coríntios. São José dos Campos: Paracletos, 2003. p. 387.

60 CALVINO, 2003, p. 386. 
1Coríntios 12.14-27, Calvino deixa bem claro que na Igreja existe uma hierarquia baseada em carismas e funções, algumas superiores a outras. ${ }^{61}$ O que daria, então, o sentido de ação para esses membros? Como é possível que todos sejam chamados para o cumprimento de uma missão comum? A resposta para essas questões encontra-se no conceito do sacerdócio universal ou real dos crentes, que dá sentido tanto para o culto da igreja como para o seu ministério. ${ }^{62}$ Mas o que vem a ser, na concepção de Calvino, o sacerdócio universal ou real dos crentes? Calvino escreve:

Em função deste ofício, que consiste em oferecer sacrifício, todos nós, cristãos, somos chamados sacerdócio real, porque por Jesus Cristo oferecemos sacrifício de louvor a Deus, quer dizer, o fruto de lábios que confessam o Seu nome, como nos disse o apóstolo. Porquanto com os nossos dons e presentes não poderíamos comparecer à presença de Deus sem um intercessor. E Jesus Cristo é o Mediador que intercede por nós e pelo qual nos oferecemos ao Pai, com tudo o que é nosso. Ele é o nosso sumo sacerdote. ${ }^{63}$

Por meio dessa concepção, portanto, Calvino compreende que toda a articulação dos crentes, quando ao culto e ao serviço ministerial, é realizada por intermédio de Jesus Cristo, Cabeça do Corpo, Sumo-sacerdote dos sacerdotes. Por isso, cada cristão é convocado para dispor de seus dons ou carismas ao serviço para o qual foi vocacionado por Deus.

Algo que é necessário afirmar inicialmente é que o sacerdócio real dos crentes não exclui a necessidade de uma organização eclesiástica. Devemos lembrar que os conflitos teológicos de Calvino não se travavam apenas contra os católicos. Os grupos anabatistas também era opositores contra os quais Calvino também investia seus escritos, porquanto, estes grupos tinha uma interpretação das Escrituras e da própria teologia que alçava voos inimagináveis inconcebíveis para os reformadores, inclusive Calvino. ${ }^{64}$ Se o primeiro grupo dava ênfase na hierarquia, o segundo a ignorava por completo. Nesse sentido, o sacerdócio real dos crentes não excluía que existisse uma liderança que se responsabilizasse pelo ensino da Palavra, ministração dos sacramentos e exercício da disciplina. ${ }^{65}$

Desta maneira, pode-se afirmar, que os crentes teriam, como referência de sua ação, as ações dos ministros no exercício dos seus respectivos ministérios. Nesse sentido,

61 CALVINO, 2003, p. 385-390.

62 MANNION, Gerard; VAN DER BORGHT, Eduardus (Eds.). Calvin's Eclesiology: Ecumenical Perspective. New York: T. \& T. Clark, 2011. p. 188.

63 CALVINO, 2011, p. 49.

64 Um exemplo disso era o conceito da Carne Celestial. Essa era a crença que o corpo de Jesus teria sido gerado no céu e posto no ventre da Virgem, evitando, segundo Menno Simons, que Jesus se apropriasse da carne pecaminosa, uma posição que contraria todas as afirmações cristológicas dos primeiros concílios da cristandade, coisa que os reformadores jamais ousaram questionar. Cf. GEORGE, 2000, p. 279.

65 VEITH JR., Gene Edward. Deus em ação. São Paulo: Cultura Cristã, 2007. p. 15. 
por exemplo, todos os cristãos estavam obrigados a proclamarem o evangelho de Jesus Cristo, como Calvino certa vez reivindicou num sermão:

Deus deu a conhecer a todo o mundo, e seu evangelho pregado a todas as criaturas. Portanto, devemos procurar, tanto quanto possível, convencer aqueles que são estranhos à fé, e parecem estar totalmente privados da bondade de Deus, a aceitar a salvação. Jesus Cristo não é apenas um Salvador de poucos, mas ele se oferece a todos. ${ }^{66}$

Podemos compreender, diante disso, que cada cristão deveria ter o compromisso a coparticipação numa missão - de apresentar o evangelho aqueles que estivessem próximos a ele, como, noutro momento, Calvino afirmou:

Se desejamos pertencer à igreja e ser reconhecidos como rebanho de Deus, devemos admitir que isto ocorre porque Jesus Cristo é o nosso Redentor. Não receemos ir a ele em grande número, e cada um de nós traga o seu próximo, considerando que ele é suficiente para salvar a todo. ${ }^{67}$

Em termos de ministério, a exposição das Escrituras e da são doutrina era obrigação única dos pastores e doutores da Igreja, mas, como corresponsáveis neste ministério, cada cristão era instado no participar da missão da Igreja, tornando manifesto a quantos fossem possíveis a mensagem do evangelho. Por outro lado, aos corpos diaconais estava reservado o ministério do cuidado com os pobres e todos os necessitados. No entanto, como Calvino argumentou, que aqueles que formam "a família da fé, somos os que melhor podemos apreciar a imagem de Deus, de modo que se alguém aparece diante de vocês necessitando de amáveis serviços, não há razão alguma para lhes recusar ajuda" ${ }^{68}$

Enfim, a responsabilidade do exercício do ministério da Igreja era compartilhada por todos, embora existisse distinções, dentro desse corpo. Não obstante, a diversidade e multiplicidade, todos também se articulavam de maneira interdependente - no sacerdócio universal, e com o apoio de toda junta e ligamento - os ministérios ordenados - o corpo de Cristo, que é a sua santa Igreja, vividamente prosseguiria para a sua meta proposta.

\section{Considerações Finais}

Diante do que fora exposto, fica claro que a eclesiologia de Calvino tem como responder a uma necessidade do nosso tempo. A corresponsabilidade proclama uma participação comunitária que envolva a todos no compromisso do cumprimento da missão que Cristo incumbiu a sua Igreja. Nesse sentido, a Igreja se faz inclusiva, já que todo

66 CALVIN, John. Sermon on 1Tim.2:3-5. In: CALVIN, John. Calvin's Sermons: The Mystery of Godliness. Grand Rapids: Eerdmans, 1950.

67 PARKER T. H. L. Sermons on Isaiah's Profecy of the Passion and Death of Christ. Londres: Lames Clark, 1956. p. 144.

68 CALVINO, João. A verdadeira vida cristã. 8. ed. São Paulo: Fontes, 2008. p. 39. 
membro do corpo tem uma função, um lugar e um papel. É possível aqui fazer algumas considerações oportunas a partir do exposto.

O papel do ministério ordenado inclui o gerenciamento do Corpo. Os ministros instituídos pela e na Igreja, além das funções pertinentes aos seus ofícios, devem assumir dentro de um ambiente em que a corresponsabilidade é adota um papel de gerenciamento. Não é sem sentido que Calvino utiliza as metáforas juntas e ligamentos para ilustrar a função dos ofícios. A articulação das ações da Igreja deve estar nas mãos daqueles que são divina e humanamente instituídos para determinado ministério. Nesse sentido, esse não apenas com aquela liderança que age por meio da influência positivamente exercida sobre os liderados, mas também no controle das pessoas e da execução das ações propostas pela comunidade. O ministro cristão deve, à luz da eclesiologia de Calvino, assumir primeiramente a tarefa e só depois, pelo seu próprio exemplo, estimular e orientar os demais a assumirem o seu lugar na realização da missão.

A missão da Igreja é inclusiva. Não é incomum em comunidades cristãs a omissão dos seus membros a ação missional da Igreja. Por um lado, alguns pensam que muitos já estão realizando todo o trabalho; por outro lado, alguns não se reconhece como capazes de fazer algo. Para Calvino, todos são dotados de "dons e presentes" para o exercício da missão. Todos, no corpo, têm sua função e seu espaço de ação. A missão não exclui, mas chama a todos ao envolvimento.

\section{Referências}

BARTH, Karl. The Theology of Joh Calvin. Grand Rapids: Wm. B. Eerdemans, 2000.

CALVIN, Jean. Projet D'ordonnances Ecclesiastiques (1541). In: CUNITZ, Edouard et al. (Eds.) Joannis Calvini opera quae supersunt omnia. Tomo 10. Brunsvigae: C.A. Schwetschke, 1863.

CALVIN, John. Commentary on the Epistle to the Romans. Albany: AGES Library, 1998. . Commentary on the First Epistle to Timothy. Albany: AGES Library, 1998.

- Sermon on 1Tim.2:3-5. In: CALVIN, John. Calvin's Sermons: The Mystery of Godliness. Grand Rapids: Eerdmans, 1950.

CALVINO, João. 1 Coríntios. São José dos Campos: Paracletos, 2003.

. A verdadeira vida cristã. 8. ed. São Paulo: Fontes, 2008.

. Efésios. São Paulo: Paracletos, 1998.

. Instituições da Religião Cristã. Tomo I. São Paulo: Unesp, 2009a.

. Instituições da Religião Cristã. Tomo II. São Paulo: Unesp, 2009b. 
. Institutas da Religião Cristã: edição de estudo. v. 4. São Paulo: Cultura Cristã, 2011.

. Pastorais. São José dos Campos: Fiel, 2009.

CALVINUS, Ioannis. Institutio Christianae Religionis. Berolini: Gustav Eichler, 1835. Disponível em: <http://www.ccel.org/ccel/calvin/institutio2/ Page_213.html>. Acesso em: 06 out. 2015.

CONFISSÃO DE FÉ DE WESTMINSTER. 17. ed. São Paulo: Cultura Cristã, 2001.

CONSTITUIÇÃO DA IGREJA PRESBITERIANA DO BRASIL. In: Manual Presbiteriano. 16. ed. São Paulo: Cultura Cristã, 2014. p. 19.

DECRETO APOSTÓliCO APOSTOLICAM ACTUOSITATEM. In: Documentos do Concílio Vaticano II. 2. ed. São Paulo: Paulus, 2002.

DOUGLASS, Jane Dempsey. Mulheres, Liberdade e Calvino. Manhumirim: Didaquê, 1995.

FERREIRA, Wilson Castro. Calvino: Vida, influência e teologia. Campinas: LPC, 1990.

GEORGE, Timothy. A Teologia dos Reformadores. São Paulo: Vida Nova, 2000.

JOÃO PAULO II. Carta Encíclica Slavorum Apostoli. Disponível em: <http://w2.vatican.va/content/john-paul-ii/pt/encyclicals/documents/hf_jpii_enc_19850602_slavorum-apostoli.html >. Acesso em: 14 out. 2015.

KINGDON, Robert M. Calvin's Ideas about the Diaconate: Social or Theological in Origin? In: LINDBERG, Carter (Ed.). Piety, Politics, and Ethics. Kirksville: Sixteenthcentury Journal Publishers, 1984.

LARRIBA, Jesus. Eclesiología y Antropología en Calvino. Madrid: Cristandad, 1975.

LUMEN GENTIUM, 31. In: Documentos do Concílio Vaticano II. 2. ed. São Paulo: Paulus, 2002.

MANNION, Gerard; VAN DER BORGHT, Eduardus (Eds.). Calvin's Eclesiology: Ecumenical Perspective. New York: T. \& T. Clark, 2011.

MATOS, Alderi Souza. João Calvino e a Disciplina em Genebra: Um Retrato Paradoxal. Fides Reformata, v. XVIII, n. 1, 2013.

McINTIRE, C.T. Anticlericalismo. In: ELWELL, Walter A. Enciclopédia Histórico-Teológica da Igreja Cristã. São Paulo: Vida Nova, 2009.

PARKER T. H. L. Sermons on Isaiah's Profecy of the Passion and Death of Christ. Londres: Lames Clark, 1956.

RAUSCH, Thomas P. A Teologia e seus Métodos. In: RAUSCH, Thomas P. (Org.). Introdução à Teologia. 2. ed. São Paulo: Paulus, 2009.

VEITH JR., Gene Edward. Deus em ação. São Paulo: Cultura Cristã, 2007. 